\title{
PENGARUH KOMPETENSI TERHADAP KINERJA KARYAWAN PT KERETA API INDONESIA DIVISI REGIONAL IV TANJUNG KARANG BANDAR LAMPUNG
}

\author{
Fahrizi $^{1}$, Meylinda Syafitri ${ }^{2}$ \\ Universitas Sang Bumi Ruwa Jurai \\ mey.lindah@yahoo.com
}

\begin{abstract}
ABSTRAK
Transportasi memiliki peran penting dalam mendukung pertumbuhan ekonomi. Tujuan penelitian untuk mengetahui pengaruh kompetensi terhadap kinerja karyawan P.T. Kereta Api Indonesia Devisi Regional IV Tanjung Karang Bandar Lampung. Populasi dalam penelitian ini adalah seluruh karyawan P.T. Kereta Api Indonesia Devisi Regional IV Tanjung Karang. Bandar Lampung. Sampel dalam penelitian ini berjumlah 28 orang karyawan. Teknik pengambilan sampel yang digunakan Stratified Random Sampling (SRS). Analisis data dalam penelitian ini menggunakan regresi linier sederhana. Setelah dilakukan analisis data, disimpulkan kompetensi berpengaruh terhadap kinerja karyawan P.T. Kereta Api Indonesia Devisi Regional IV Tanjung Karang Bandar Lampung. Persamaan regresi antara variabel Kinerja terhadap kinerja adalah $=9,868+0,783 X$, yang artinya setiap kenaikan satu point daripada variabel Kompetensi akan diikuti oleh naiknya variabel Kinerja Pegawai pada PT Kereta Api Indonesia (Persero) Divisi Regional IV Tanjungkarang Kota Bandar Lampung sebesar 0,783 point.
\end{abstract}

Kata Kunci: Kompetensi, Kinerja.

\section{ABSTRACT}

Transportation has an important role in supporting economic growth. The purpose of the study was to determine the effect of competence on the performance of P.T.'s employees. Kereta Api Indonesia Regional Division IV Tanjung Karang Bandar Lampung. The population in this study were all employees of P.T. Kereta Api Indonesian Regional Division IV Tanjung Karang Bandar Lampung. The sample in this study amounted to 28 employees. The sampling technique used was Stratified Random Sampling (SRS). Analysis of the data in this study uses simple linear regression. After analyzing the data, it is concluded that competence influences the performance of P.T. Kereta Api Indonesian Regional Division IV Tanjung Karang Bandar Lampung. The regression equation between the Performance variable against performance is $=9,868$ $+0.783 X$, which means that every one point increase than the Competency variable will be followed by an increase in the Employee Performance variable at PT Kereta Api Indonesia (Persero) Regional IV Division Tanjungkarang Bandar Lampung City by 0.783 points

Keywords: Competence and Performance 


\section{ENDAHULUAN}

Perkeretaapian di Indonesia sebagai sistem moda transportasi nasional yang mempunyai karakteristik pengangkutan massal dan keunggulan tersendiri serta tidak dapat dipisahkan dari moda transportasi lain, ternyata perlu dikembangkan potensinya serta ditingkatkan peranannya sebagai penghubung wilayah, dengan maksud untuk menunjang, mendorong, dan menggerakkan pembangunan nasional guna meningkatkan kesejahteraan rakyat. Idealnya, perkeretaapian bertujuan memperlancar perpindahan orang dan/atau barang secara massal dengan selamat, aman, nyaman, cepat dan lancar, tepat, tertib dan teratur, efisien, serta menunjang pemerataan, pertumbuhan, stabilitas, pendorong, dan penggerak pembangunan nasional.

Idealisme penyelenggaraan transportasi perkeretaapian diperlukan peran sumber daya manusia yang memiliki kompetensi, sebab sumber daya manusia (SDM) merupakan faktor yang harus diperhatikan karena memegang peranan yang sangat penting dalam sebuah usaha, meskipun pesatnya perkembangan teknologi saat ini, namun faktor manusia tetap memegang peranan penting bagi keberhasilan suatu usaha. Perkataan lain yang dapat diungkap dalam penelitian ini karena sumber daya manusia merupakan komponen utama sebagai penggerak dalam setiap kegiatan usaha untuk peningkatan kinerja atau kemajuan perusahaan. Dalam hal ini kinerja merupakan tingkat pencapaian hasil atas pelaksanaan tugas tertentu, atau kinerja juga dapat dipandang sebagai proses tentang bagaimana pekerjaan berlangsung untuk mencapai hasil kerja, kinerja di dalam perusahaan dilakukan oleh segenap sumber daya manusia dalam organisasi baik unsur pimpinan maupun karyawan. Seorang karyawan yang memiliki kinerja yang tinggi dapat menunjang tercapainya tujuan perusahaan. Hal ini dimaksudkan sebagaiupayapencapaianyangterdorong oleh karena adanya visi Perkeretaapian, antara lain mewujudkan eksistensi sebagai regulator dan penyelenggaraan perkeretaapian multi operator guna terselenggaranya pelayanan angkutan kereta api secara massal yang menjamin keselamatan, aman, nyaman, cepat dan lancar, tertib dan teratur, efisien, terpadu dengan moda transportasi lain, serta menunjang pemerataan, pertumbuhan, stabilitas, pendorong, dan penggerak pembangunan nasional. Namun pada Divisi Regional IV Tanjungkarang, pencapaian visi belum terlaksana, sebab dari sisi usaha penyelenggaraan perkeretaapian, belum ada peningkatkan peran Pemerintah selaku regulator penyelenggaraan perkeretaapian, penyelenggaraan perkeretaapian multioperator dengan peningkatan peran Pemerintah Daerah dan swasta, peran Kereta Api sebagai angkutan publik, sebagai tulang punggung angkutan barang dan sebagai pelopor terciptanya angkutan terpadu belum terwujud secara maksimal. Penyebabnya karena masih ada sebagian karyawan pada Perkeretaapian Divisi Regional IV Tanjungkarang belum maksimal melaksanakan tugas pokok terutama merumuskan dan melaksanakan kebijakan serta standarisasi teknis di 
bidang perkeretaapian. Seharusnya kompetensi karyawan secara keseluruhan mampu melaksanakan fungsi pekerjaan terutama kemampuan menyiapkan perumusan kebijakan Kementerian Perhubungan di bidang lalu lintas dan angkutan kereta api, teknik prasarana, keselamatan dan teknik sarana kereta api dengan cara melaksanakan kebijakan di bidang lalu lintas dan angkutan kereta api, teknik prasarana, keselamatan dan teknik sarana kereta api, penyusunan standar, norma, pedoman, kriteria dan prosedur di bidang lalu lintas dan angkutan kereta api, teknik prasarana, keselamatan dan teknik sarana kereta api dan adanya pemberian bimbingan teknis dan evaluasi di bidang perkeretaapian serta pelaksanaan administrasi Direktorat Jenderal Perkeretaapian.

Pada Perkeretaapian Divisi Regional IV Tanjungkarang, fasilitas penunjang kereta api masih kurang terutama sebagai segala sesuatu yang melengkapi penyelenggaraan angkutan kereta api yang dapat memberikan kemudahan, kenyamanan, dan keselamatan bagi pengguna jasa kereta api dimana pengguna jasa diberikan untuk angkutan orang maupun barang. Sebab PT KAI adalah perusahan satu-satunya milik pemerintah yang menyediakan jasa transportasi kereta api. Sebagai penyedia jasa perkeretaapian Indonesia sudah seharusnya PT KAI terutama pada Divisi Regional IV Tanjungkarang para karyawannya berkompeten dalam memahami terutama dalam menyediakan fasilitasfasilitas untuk mendukung kenyamanan dan keamanan para pengguna jasanya.
Melihat dari realita yang ada saat ini hal-hal tersebut belum dapat terealisasi. Masih banyak fasilitas-fasilitas penunjang yang belum ada, ada pula fasilitas yang sudah ada tetapi tidak dilakukan perawatan sehingga saai ini sudah tidak layak guna. Sistem pembelian tiket, keamanan, kenyamanan kendaraan, kebersihan kereta dan stasiun masih harus diperbaiki tiap tahunnya. Setidaknya PT. KAI dalam hal ini pihak pengelola sebagai pencapai kinerja harus berkaca dari pengalaman yang sudah-sudah sehingga masalah seperti itu terus terjadi tiap tahunnya. Sebab seiring perkembangan zaman dan teknologi maka sumberdaya manusia dalam perusahaan PT.KAI harus memiliki sumber daya manusia yang berkompetensi, sehingga perusahaan akan berkembang dan mampu bertahan dalam persaingan yang kompetitif pada era globalisasi ini apabila didukung oleh karyawan yang memiliki pengetahuan yang luas dan berkompeten dibidangnya agar karyawan mampu menyelesaikan pekerjaannya dengan baik menurut Flippo (2014:78) "seseorang agar mencapai kinerja yang tinggi tergantung pada kerja sama, kepribadian, kepandaian yang beraneka ragam, kepemimpinan, keselamatan, pengetahuan pekerjaan, kehadiran, kesetiaan, ketangguhan dan inisiatif". Sehingga kemampuan karyawan dapat ditunjang dengan tingkat pengetahuan berkaitan erat dengan kemampuan profesionalitas karyawan yang akan terlihat dari kinerja karyawan secara kualitas dan kuantitas hasil pekerjaanya.

Beranjak dari latar belakang sebagimana disebutkan di atas, kami 
mencoba melakukan penelitian dengan judul "Pengaruh Kompetensi Terhadap Kinerja Karyawan PT. Kereta Api Indonesia Divisi Regional IV Tanjungkarang".

\section{KERANGKA PEMIKIRAN}

Idealnya, perkereta apian diselenggarakan memperlancar perpindahan orang dan/atau barang secara massal dengan selamat, aman, nyaman, cepat dan lancar, tepat, tertib dan teratur, efisien, serta menunjang pemerataan, pertumbuhan, stabilitas, pendorong, dan penggerak pembangunan nasional.

Fasilitas penunjang perkeretaapian Divisi Regional IV Tanjungkarang, masih kurang terutama sesuatu yang melengkapi penyelenggaraan angkutan agar memberikan kemudahan, kenyamanan, dan keselamatan bagi pengguna jasa kereta api, sebab PT KAI adalah perusahan satu-satunya milik pemerintah yang menyediakan jasa transportasi kereta api. Sebagai penyedia jasa sudah seharusnya PT KAI terutama pada Divisi Regional IV Tanjungkarang para karyawannya berkompeten dan memahami terutama dalam menyediakan fasilitas-fasilitas untuk mendukung kenyamanan dan keamanan para pengguna jasanya. Melihat dari realita yang ada saat ini hal-hal tersebut belum dapat terealisasi. Masih banyak fasilitas-fasilitas penunjang yang belum ada, ada pula fasilitas yang sudah ada tetapi tidak dilakukan perawatan sehingga saat ini sudah tidak layak guna. Sistem pembelian tiket, keamanan, kenyamanan kendaraan, kebersihan kereta dan stasiun masih harus diperbaiki tiap tahunnya. Setidaknya PT. KAI selaku pihak pengelola sebagai pencapai kinerjanya harus berkaca dari pengalaman yang sudah-sudah sehingga masalah seperti itu tidak selalu terus terjadi tiap tahunnya. Sebab seiring perkembangan zaman dan teknologi maka sumberdaya manusia dalam perusahaan PT.KAI harus memiliki sumber daya manusia yang berkompetensi, sehingga perusahaan akan berkembang dan mampu bertahan dalam persaingan yang kompetitif pada era globalisasi ini apabila didukung oleh karyawan yang memiliki pengetahuan yang luas dan berkompeten dibidangnya sehingga karyawan mampu menyelesaikan pekerjaannya dengan baik dalam bentuk prestasi atau kinerja. Menurut Flippo (2014:78) "seseorang agar mencapai kinerja yang tinggi tergantung pada kerja sama, kepribadian, kepandaian yang beraneka ragam, kepemimpinan, keselamatan, pengetahuan pekerjaan, kehadiran, kesetiaan, ketangguhan dan inisiatif". kemampuan karyawan dapat ditunjang dengan tingkat pengetahuan berkaitan erat dengan kemampuan profesionalitas karyawan yang akan terlihat dari kinerja karyawan secara kualitas dan kuantitas hasil pekerjaanya.

Berdasarkan gambaran di atas, kerangka pikir yang dapat digambarkan sebagai berikut : 


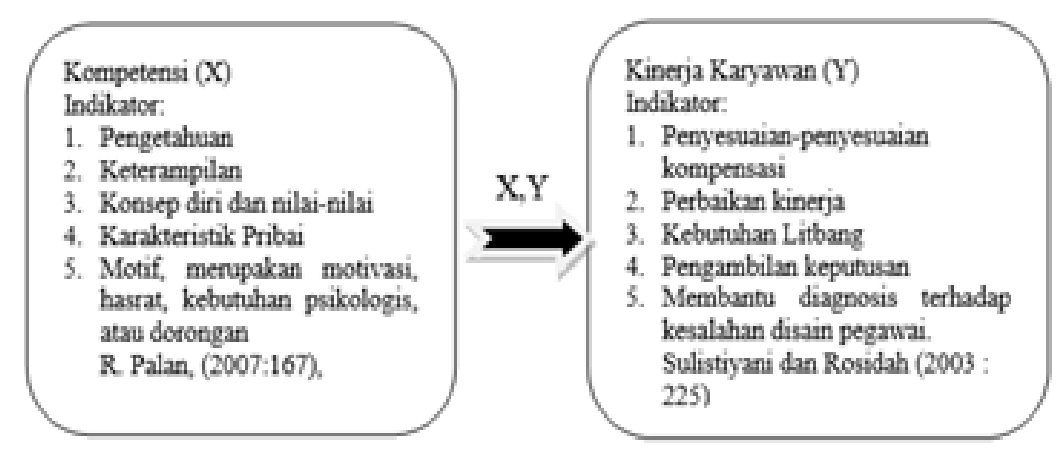

Gambar 1. Kerangka Pikir Kompetensi dan Kinerja Karyawan

\begin{abstract}
Hipotesis yang diajukan: "ada pengaruh antara Kompetensi terhadap kinerja Karyawan PT. Kereta Api Indonesia Divisi Regional IV Tanjungkarang".
\end{abstract}

\section{METODOLOGI PENELITIAN}

Penulisan ini melihat pengaruh antara Kompetensi terhadap kinerja Karyawan PT. Kereta Api Indonesia Divisi Regional IV Tanjungkarang dengan metode penelitian yang dipergunakan adalah metode analisis diskriftif, yaitu suatu penganalisaan yang menggambarkan permasalahan yang terjadi dan diuraikan secara sistematis. Kemudian dari data-data setidaknya akan diperoleh suatu kesimpulan permasalahan yang lebih jelas dan terinci guna mencari pemecahan masalah yang dihadapi berupa penyebaran kuesioner dan juga tanya jawab.

Teknik Pengumpulan Data yang digunakan dalam penelitian ini adalah :

1. Observasi, teknik ini melakukan penelitian dan pengamatan langsung dengan cara mendekati objek yang akan diteliti. Observasi ini penulis lakukan untuk mengetahui tentang permasalahan Kompetensi dan Kinerja Karyawan PT. Kereta Api Indonesia Divisi Regional IV Tanjungkarang

2. Angket Pertanyaan, langkah ini melakukan pengumpulan data dengan menyebarkan daftar pertanyaan kepada pejabat dan Karyawan PT. Kereta Api Indonesia Divisi Regional IV Tanjungkarang. Kuesioner adalah pengumpulan data yang dilakukan dengan memberi seperangkat pertanyaan atau pernyataan tertulis kepada responden untuk dijawabnya (Sugiono, 2011:142)

3. Telaah Dokumentasi dan Kepustakaan, telaahan ini yaitu tekhnik pengumpulan data yang dilakukan dengan mengkaji bukubuku bacaan, dokumen-dokumen, peraturan-peraturan dan ketentuan undang-undang serta kebijaksanaankebijaksanaan yang berkaitan dengan pokok permasalahan.

Penulisan ini menggunakan teknik pengambilan sampel secara Stratified Random Sampling (SRS) yaitu pengambilan suatu data sampel yang diambil secara berurutan berdasarkan deret waktu. 


\section{HASIL DAN PEMBAHASAN}

Penelitian dilakukan terhadap 28 responden melalui penyebaran kuesioner, dimana untuk mendapatkan kecenderungan jawaban responden terhadap jawaban masing-masing variabel yang didasarkan pada rentang skor jawaban, hasilnya yakni :
A. Deskripsi Variabel Kompetensi dan Kinerja Karyawan.

Variabel Kompetensi dan Kinerja Karyawan pada penelitian ini diukur melalui masing-masing 10 buah pernyataan yang menggambarkan indikator-indikator dari variabel tersebut. Hasil tanggapan terhadap Kompetensi dan Kinerja Karyawan dapat dijelaskan pada tabel 1 berikut:

Tabel 1. Tanggapan responden mengenai Kompetensi (X) dan Kinerja Karyawan (Y)

\begin{tabular}{|c|c|c|c|c|c|c|}
\hline \multirow{2}{*}{ Pernyataan } & \multicolumn{5}{|c|}{ Skor } & \multirow{2}{*}{ Jumlah } \\
\hline & SS & $S$ & $\mathrm{Rg}$ & TS & STS & \\
\hline \multirow[t]{2}{*}{$\mathrm{X}$} & 3 & 22 & 3 & - & - & 28 \\
\hline & $10.71 \%$ & $78,57 \%$ & $10,71 \%$ & $0.0 \%$ & $0.0 \%$ & $100.0 \%$ \\
\hline \multirow[t]{2}{*}{$\mathrm{Y}$} & 5 & 23 & - & - & - & 28 \\
\hline & $17,86 \%$ & $82,14 \%$ & $0.0 \%$ & $0.0 \%$ & $0.0 \%$ & $100.0 \%$ \\
\hline
\end{tabular}

Sumber: Data primer yang diolah, 2017

\section{B. Analisa Pembahasan Kualitatif.}

Berdasarkan hasil penyebaran daftar pertanyaan yang diajukan kepada responden Divisi Regional IV Tanjungkarang sebanyak 28 responden berkaitan dengan Kompetensi (X) yang meliputi Penetapan pekerjaan apa yang sudah dilaksanakan, menilainya dan mengoreksi bila perlu dengan maksud supaya pelaksanaan pekerjaan sesuai dengan rencana-rencana semula, upaya memeriksa apakah semua terjadi sesuai dengan rencana yang ditetapkan, perintah yang dikeluarkan dan prinsip yang dianut juga dimaksudkan untuk mengetahui kelemahan dan kesalahan agar dapat dihindari kejadiannya dikemudian hari, dapat dilihat pada tabel berikut:
Tabel 2. Kompetensi Karyawan pada PT Kereta Api Indonesia (Persero) Divisi Regional IV Tanjungkarang Kota Bandar Lampung

\begin{tabular}{clcc}
\hline No & $\begin{array}{l}\text { Menjawab } \\
\text { Pernyataan }\end{array}$ & Kompetensi & Persantase \\
\hline 1 & $\begin{array}{l}\text { Sangat Setuju } \\
\text { (SS) }\end{array}$ & 5 & 10,21 \\
2 & Setuju (S) & 19 & 73,47 \\
3 & Kurang Setuju & 4 & 16,32 \\
& (Ks) \\
4 & Tidak Setuju & - & - \\
& (TS) \\
5 & Sangat Tidak & - & - \\
& Setuju (STS) & & \\
\hline \multicolumn{2}{c}{ Jumlah } & 28 & 100 \\
\hline
\end{tabular}

Sumber : Data Hasil Pengolahan 
Dari tabel 2 dasar daftar pertanyaan yang diajukan kepada responden, yang menyatakan memiliki pengetahuan dengan merujuk pada informasi dan hasil pembelajaran sebagai bentuk kompetensi dari karyawan atau menjawab pernyataan dengan sangat setuju (SS) dalam hal keterampilan yang merujuk pada kemampuan seseorang karyawan untuk melakukan suatu kegiatan, adalah 5 orang atau 10,21 $\%$. Sedangkan responden yang merasa mampu setelah diawasi pekerjaan dengan jawaban pernyataan setuju (S), antara lain dalam hal memahami konsep diri dan nilai-nilai, merujuk pada sikap, nilai-nilai dan citra diri seseorang serta karakteristik Pribadi yang merujuk pada karakteristik fisik dan konsistensi tanggapan terhadap situasi atau informasi sebanyak 19 orang atau 73,47 $\%$. Namun ada juga responden yang menyatakan atau jawaban pernyataan kurang setuju (KS), antara lain dalam hal memahami karakteristik Pribadi, merujuk pada karakteristik fisik dan konsistensi tanggapan terhadap situasi atau informasi dan juga motif yang merupakan motivasi, hasrat, kebutuhan psikologis, atau dorongan-dorongan lain yang memicu tindakan sebanyak 4 orang atau $16,32 \%$.

Kemudian berdasarkan hasil penyebaran daftar pertanyaan yang diajukan kepada responden Karyawan pada PT Kereta Api Indonesia (Persero) Divisi Regional IV Tanjungkarang Kota Bandar Lampung sebanyak 28 responden berkaitan dengan Kinerja Karyawan pada PT Kereta Api Indonesia (Persero) Divisi Regional IV Tanjungkarang Kota Bandar Lampung

dapat dilihat pada tabel berikut:

Tabel 3. Kinerja Kerja Karyawan
pada PT Kereta Api Indonesia

(Persero) Divisi Regional IV

Tanjungkarang

Kota Bandar Lampung

\begin{tabular}{clcc}
\hline No & $\begin{array}{l}\text { Menjawab Per- } \\
\text { nyataan }\end{array}$ & Kinerja & Persantase \\
\hline 1 & $\begin{array}{l}\text { Sangat Setuju } \\
\text { (SS) }\end{array}$ & 5 & 17,86 \\
2 & $\begin{array}{l}\text { Setuju (S) } \\
\text { Kurang Setuju } \\
\text { (Ks) }\end{array}$ & 23 & 82,14 \\
4 & $\begin{array}{l}\text { Tidak Setuju } \\
\text { (TS) }\end{array}$ & - & - \\
5 & $\begin{array}{l}\text { Sangat Tidak } \\
\text { Setuju (STS) }\end{array}$ & - & - \\
\hline & $\quad$ Jumlah & 28 & 100 \\
\hline
\end{tabular}

Sumber : Data Hasil Pengolahan, 2017

Dari tabel atas dasar daftar pertanyaan yang diajukan, maka yang menyatakan mampu memimpin diri dalam pekerjaan sebagai bentuk kinerja dengan menjawab pernyataan sangat setuju (SS) dalam hal Penyesuaianpenyesuaian kompensasi dan Perbaikan kinerja adalah 5 orang atau 17,86\%. Sedangkan responden yang mampu menghasilkan kinerja dengan jawaban pernyataan setuju (S), dalam hal penyesuaian-penyesuaian kompensasi, Perbaikan kinerja, Kebutuhanlatihandan pengembangan, Pengambilan keputusan dan juga dalam hal penempatan, promosi, mutasi, pemecatan, pemberhentian dan perencanaan tenaga kerja untuk kepentingan penelitian Karyawan dan membantu diagnosis terhadap kesalahan disain Karyawan adalah 23 orang atau $82,14 \%$. 


\section{Uji Kualitas Data \\ Uji Validitas}

Uji validitas adalah penyesuaian data (ajusting data) yang dipergunakan untuk mengetahui tingkat kesesuaian dari instrumen kuesioneryang digunakan dalam pengumpulan data. Uji validitas dilakukan untuk mengetahui apakah item-item yang tersaji dalam kuesioner benar-benar mampu mengungkapkan tanggapan responden dengan pasti berkaitan dengan apa yang akan diteliti oleh peneliti.

Selanjutnya untuk syaratminimum agar dianggap memenuhi syarat valid adalah dengan mengkorelasikan masing-masing dengan skor total variabel. Kemudian angka korelasi yang dihasilkan akan dibandingkan dengan nilai $r$ tabel pada $\alpha 0,05$ dengan $\mathrm{df}$ (degree of freedom) $=28$ yaitu sebesar 0,381. Dengan demikian berdasarkan uji validitas maka butir dalam instrumen tersebut dinyatakan valid apabila nilai $\mathrm{t}$ hitung skor item terhadap skor totalnya lebih besar $(>)$ dari 0,381 atau dikatakan tidak valid apabila nilai $\mathrm{t}$ hitung skor item terhadap skor totalnya lebih kecil $(<)$ dari 0,381. Oleh karenanya, semakin baik nilai koefisien korelasi pearson suatu item, memperlihatkan semakin baik validitas item tersebut. Pengujian terhadap tingkat keandalan kuesioner dalam penelitian ini dilakukan dengan menggunakan salah satu paket program komputer pengolahan data statistika, yaitu SPSS Versi 21.0 dengan menggunakan alpha cronbach. Variabel dikatakan reliabel bila koefisien alpha lebih besar dari 0,381. Uji validitas digunakan untuk menguji sejauh mana suatu alat pengukur dapat mengukur atau mengungkapkan konsep gejala/ kejadian yang diukur. Sehingga dapat disimpulkan bahwa semua item pertanyaan dinyatakan valid.

\section{Uji Reliabilitas Data}

Uji Reliabilitas (keterpercayaan) yang dipergunakan adalah untuk mengetahui layak tidaknya data responden yang digunakan dalam penelitian. Untuk uji releabilitas ini digunakan Teknik Alpha Cronbach, dimana suatu instrumen dikatakan handal (reliabel) bila memiliki koefisien keandalan atau alpha sebesar 0,5 atau lebih. Dengan menggunakan rumusan reliabilitas dari Alpha Cronbach tersebut, maka didapat hasil:

a. Uji Reliabilitas Variabel Kompetensi (X)

Hasil uji Reliabilitas Variabel Kompetensi (X) berdasarkan jawaban responden terhadap 10 Pernyataan dengan jumlah responden ( $\mathrm{N}$ of Cases) sebesar 28 dan jumlah item pernyataan ( $\mathrm{N}$ of Items) alpha total sebesar 0,837. Dari 10 item pernyataan nilai alpha if item deleted seluruhnya menunjukkan reliabel, karena nilai 10 item pernyataan lebih besar dari 0,536.

b. Uji Reliabilitas Variabel Kinerja (Y) Hasil uji Reliabilitas Variabel Kinerja (Y) berdasarkan jawaban responden terhadap 10 Pernyataan dengan jumlah responden $(\mathrm{N}$ of Cases) sebesar 28 dan jumlah 10 item pernyataan ( $\mathrm{N}$ of Items) alpha total sebesar 0,742. Dari 10 item pernyataan nilai alpha if item deleted seluruhnya menunjukkan reliable, 
karena nilai 10 item pernyataan lebih besar dari 0,447 .

\section{Uji Hipotesis Pengaruh Kompetensi (X) terhadap Kinerja (Y)}

Untuk mengetahui pengaruh kompetensi (X) sebagai variabel bebas terhadap Kinerja (Y) sebagai variabel terikat dapat dilihat pada tabel berikut:

\section{Tabel 4. Uji Hipotesis Pengaruh Kompetensi (X) terhadap Kinerja (Y)}

\begin{tabular}{|c|c|c|c|c|c|}
\hline \multirow[t]{2}{*}{ Model } & \multicolumn{2}{|c|}{$\begin{array}{c}\text { Unstandarized } \\
\text { Coefficients }\end{array}$} & $\begin{array}{c}\text { Stan- } \\
\text { darized } \\
\text { Coeffi- } \\
\text { cients }\end{array}$ & \multirow[t]{2}{*}{$\mathrm{t}$} & \multirow[t]{2}{*}{ Sig. } \\
\hline & B & $\begin{array}{l}\text { Std. } \\
\text { Error }\end{array}$ & Beta & & \\
\hline $\begin{array}{l}\text { (Con- } \\
\text { stant) }\end{array}$ & 9.868 & 2.217 & & 4.451 & .000 \\
\hline $\begin{array}{l}\text { Kompe- } \\
\text { tensi }\end{array}$ & .783 & .059 & .934 & 13.362 & 000 \\
\hline
\end{tabular}

a. Dependent Variable: KINERJA

Hasil uji $\mathrm{t}$ didapat nilai $\mathrm{t}_{\text {hitung }}$ $=13,362$. Apabila dibandingkan dengan ttabel pada taraf signifikan 0,05 yaitu 3,81 , maka $\mathrm{t}_{\text {hitung }}=13,362>\mathrm{t}_{\text {tabel }} 3,81$ sehingga disimpulkan bahwa hipotesa yang menyatakan terdapat pengaruh antara variabel Kompetensi (X) terhadap Kinerja (Y) pada PT Kereta Api Indonesia (Persero) Divisi Regional IV Tanjungkarang Kota Bandar Lampung terbukti. Jadi variabel Kompetensi (X) berpengaruh terhadap Kinerja (Y).

Koefisien Determinasi $=\mathrm{R}^{2}$ $=0,9342=0,873=0,873 \times 100=$ $87,3 \%$. Dapat disimpulkan bahwa variabel Kompetensi menjelaskan variasi perubahan terhadap variabel
Kinerja pada karyawan PT Kereta Api Indonesia (Persero) Divisi Regional IV Tanjungkarang Kota Bandar Lampung sebesar 87,3\%, sedangkan sisanya dijelaskan oleh faktor lain yang tidak dikaji dala penelitian ini. Persamaan regresi antara variabel Kompetensi terhadap Kinerja adalah $\mathrm{Y}=9,868+0,783 \mathrm{X}$, yang artinya setiap kenaikan satu point daripada variabel Kompetensi akan diikuti oleh naiknya variabel Kinerja pada PT Kereta Api Indonesia (Persero) Divisi Regional IV Tanjungkarang Kota Bandar Lampung sebesar 0,783 point.

Dari hasil penelitian di nyatakan bahwa Kompetensi pegawai pada PT Kereta Api Indonesia (Persero) Divisi Regional IV Tanjungkarang Kota Bandar Lampung dari hasil uji $\mathrm{t}$ didapat nilai thitung $=13,362$. Apabila dibandingkan dengan ttabel pada taraf signifikan 0,05 yaitu 3,81 , maka thitung $=13,362>$ ttabel 3,81 kesimpulannya bahwa hipotesa yang menyatakan terdapat pengaruh antara variabel Kompetensi (X) terhadap Kinerja (Y) pada PT Kereta Api Indonesia (Persero) Divisi Regional IV Tanjungkarang Kota Bandar Lampung terbukti. Jadi variabel Kompetensi (X) berpengaruh terhadap variabel kinerja (Y) dapat diterima. Kemudian berdasarkan Koefisien Determinasi $(\mathrm{KD}) \mathrm{R}^{2}=0,9342=$ $0,873=0,873 \times 100=87,3 \%$. Dapat disimpulkan bahwa variabel Kompetensi menjelaskan variasi perubahan terhadap variabel kinerja pada PT Kereta Api Indonesia (Persero) Divisi Regional IV Tanjungkarang Kota Bandar Lampung sebesar 87,3\%, sedangkan sisanya dijelaskan oleh faktor lain yang tidak 
dikaji dala penelitian ini. Selanjutnya persamaan regresi antara variabel Kompetensi terhadap Kinerja adalah Y $=9,868+0,783 \mathrm{X}$, yang artinya setiap kenaikan satu point daripada variabel Kinerja akan diikuti oleh naiknya variabel kinerja pada PT Kereta Api Indonesia (Persero) Divisi Regional IV Tanjungkarang Kota Bandar Lampung sebesar 0,783 point.

Menurut pendapat dan hemat peneliti, diterimanya hipotesis yang menyatakan terdapat pengaruh antara variabel motivasi $(\mathrm{X})$ terhadap variabel kinerja (Y) di PT Kereta Api Indonesia (Persero) Divisi Regional IV Tanjungkarang Kota Bandar Lampung, karena dari hasil perhitungan Koefisien Determinasi $(\mathrm{KD})=\mathrm{R}^{2}=0,9342=$ $0,873=0,873 \times 100=87,3 \%$, yang diartikan variabel Kompetensi (X) menjelaskan variasi perubahan terhadap variabel Kinerja (Y) di PT Kereta Api Indonesia (Persero) Divisi Regional IV Tanjungkarang Kota Bandar Lampung sebesar $87,3 \%$, sedangkan sisanya sebesar $12,7 \%$ dijelaskan oleh faktor lain yang tidak dikaji dalam penelitian ini. Kemudian dalam persamaan regresi antara variabel Kompetensi (X) terhadap variabel Kinerja (Y) adalah $\mathrm{Y}$ $=9,868+0,783 \mathrm{X}$, yang artinya setiap kenaikan satu point daripada variabel Kompetensi akan diikuti oleh naiknya variabel Kinerja pada PT Kereta Api Indonesia (Persero) Divisi Regional IV Tanjungkarang Kota Bandar Lampung sebesar 0,783 point, karena Kinerja pegawai di PT Kereta Api Indonesia (Persero) Divisi Regional IV Tanjungkarang Kota Bandar Lampung ini terdukung oleh adanya sikap karyawan yang memiliki orientasi pada prestasi, memiliki percaya diri, berpengendalian diri dan kompetensi.

\section{KESIMPULAN}

Berdasarkan hasil uji $\mathrm{t}$ didapat nilai thitung $=13,362$. Dan bila dibandingkan dengan ttabel pada taraf signifikan 0,05 yaitu 3,81 , maka thitung $=13,362>$ ttabel 3,81 kesimpulannya bahwa hipotesa yang menyatakan terdapat pengaruh antara variabel Kompetensi (X) terhadap Kinerja (Y) pada PT Kereta Api Indonesia (Persero) Divisi Regional IV Tanjungkarang Kota Bandar Lampung terbukti. Jadi variabel Kompetensi (X) berpengaruh terhadap variabel Kinerja (Y) dapat diterima. Kemudian berdasarkan Koefisien Determinasi (KD) $\mathrm{R} 2=0,9342=0,873=0,873 \mathrm{x}$ $100=87,3 \%$. Dapat disimpulkan bahwa variabel Kompetensi menjelaskan variasi perubahan terhadap variabel kinerja pegawai pada PT Kereta Api Indonesia (Persero) Divisi Regional IV Tanjungkarang Kota Bandar Lampung sebesar $87,3 \%$, sedangkan sisanya dijelaskan oleh faktor lain yang tidak dikaji dala penelitian ini. Sedangkan persamaan regresi antara variabel Kinerja terhadap kinerja adalah $=9,868$ $+0,783 \mathrm{X}$, yang artinya setiap kenaikan satu point daripada variabel Kompetensi akan diikuti oleh naiknya variabel Kinerja Pegawai pada PT Kereta Api Indonesia (Persero) Divisi Regional IV Tanjungkarang Kota Bandar Lampung sebesar 0,783 point. 


\section{SARAN}

1. Bagi para pegawai Kompetensi harus diperkuat, karena para karyawan diwajibkan memahami secara benar tentang pengetahuan perkeratapian yang merujuk pada mengetahui informasi dari sebuah hasil pembelajaran. Keterampilan, merujuk pada kemampuan seseorang untuk melakukan suatu kegiatan. Konsep diri dan nilai-nilai, merujuk pada sikap, nilai-nilai dan citra diri seseorang. Karakteristik Pribadi, merujuk pada karakteristik fisik dan konsistensi tanggapan terhadap situasi atau informasi. Motif, merupakan motivasi, hasrat, kebutuhan psikologis, atau dorongandorongan lain yang memicu tindakan.

2. Kemudian untuk meningkatkan kinerja hendaknya para pegawai atau karyawan harus meningkatkan kinerja karena hal ini adalah sebagi hasil kerja secara kualitas yang dicapai oleh para karyawan dalam melaksanakan tugasnya yang disesuaikan dengan tanggung jawab yang diberikan. Sehingga dengan hal ini karyawan atau pegawai secara individu akan memiliki kinerja yang tinggi dengan selalu berpedoman pada penyesuaian - penyesuaian kompensasi yang diberikan. Adanya perbaikan kinerja. Adanya kebutuhan latihan dan pengembangan. Pemahaman dalam pengambilan keputusan terutama informasi penempatan, promosi, mutasi, pemecatan, pemberhentian dan perencanaan tenaga kerja untuk kepentingan penelitian Karyawan. Membantu diagnosis terhadap kesalahan disain Karyawan.

\section{DAFTAR PUSTAKA}

Arikunto Suharsimi, 2002, Prosedur Penulisan, Penerbit Bina Aksara, Jakarta

Amstrong, M, 1999. Manajemen

Sumber Daya Manusia, Seri

Pedoman Manajemen, Alih bahasa

Sofyan Cikmat dan Haryanto, PT

Gramedia, Jakarta.

Gibson, L James, 1987, Perilaku

Organisasi, Erlangga, .Jakarta

Hasibuan, Malayu S.P..,2001.

Manajemen Sumber Daya

Manusia. Bumi Aksara. Jakarta.

Mangkunegara, A.A. Anwar Prabu, 2001, Manajemen Sumber Daya

Manusia Perusahaan, PT. Remaja

Rosdakarya, Bandung.

Prijodarminto, 2001. Motivasi Kuat

Menuju Sukses. Penerbit Rineka Cipta. Jakarta.

Priyatno, 2008. Statistik Untuk

Penelitian. Cetakan 4. Bandung : Alfabeta.

Sedarmayanti. 2001. Manajemen

Sumber daya Manusia, Reformasi

Birokrasi dan Manajemen

Karyawan Negeri Sipil. Bandung: Refika Aditama

Siagian, Sondang P. 1995.

Pengembangan Sumber Daya

Manusia. Jakarta: Gunung Agung Rosiydah, Sulistyaningsih, Sinungan, Muchdarsyah, 2005, Manajemen Personalia, Jakarta: Penerbit Ghalia Indonesia 